\title{
Az integratív medicina képzésének hazai koncepciója nemzetközi minták alapján
}

\author{
Eőry Ajándék dr. ${ }^{* 1,2}$. Szabó János dr. ${ }^{* 3,4}$. Csik Ivett dr. ${ }^{1}$ \\ Csupor Dezső dr. ${ }^{5}$. Sőti Csaba dr. ${ }^{6}$ - Kalabay László dr. ${ }^{3}$. Varsányi Péter ${ }^{1}$ \\ Komsa Ildikó ${ }^{1}$. Eôry Ajándok dr. ${ }^{* 7,8}$. Torzsa Péter dr. ${ }^{* *}, 4$ \\ 'Semmelweis Egyetem, Általános Orvostudományi Kar, Családorvosi Tanszék, \\ Integratív Medicina Tanszéki Csoport, Budapest \\ ${ }^{2}$ Egészségügyi Szakmai Kollégium, Komplementer Medicina Tanács, Budapest \\ ${ }^{3}$ Semmelweis Egyetem, Általános Orvostudományi Kar, Családorvosi Tanszék, Budapest \\ ${ }^{4}$ Egészségügyi Szakmai Kollégium, Háziorvostan Tagozat, Budapest \\ ${ }^{5}$ Szegedi Tudományegyetem, Gyógyszerésztudományi Kar, Szeged \\ ${ }^{6}$ Semmelweis Egyetem, Általános Orvostudományi Kar, Orvosi Vegytani Intézet, Budapest \\ ${ }^{7}$ Magyar Akupunktúra és Moxaterápiás Egyesület, Budapest \\ ${ }^{8}$ Egészségügyi Szakmai Kollégium, Komplementer Medicina Tagozat, Budapest
}

\begin{abstract}
Az integratív medicina a XXI. századi egészségügyi ellátás egészség- és személyközpontú irányvonala, mely az evidenciákon alapuló, biztonságos és hatékony komplementer eljárásokat és a konvencionális orvoslást egységes biomedicinába integrálja. Orvosok és komplementer terapeuták partnerként együtt dolgoznak a betegekkel azon, hogy az utóbbiak visszanyerjék egészségüket, és teljes életet élhessenek. Ezzel egyenrangú cél az egészség fenntartása és kiteljesítése, ebben az orvosok példaképpé válnak. Közleményükben a szerzők a szakorvosok számára tervezett kétéves magyarországi képzés koncepcióját és fóbb tartalmi elemeit mutatják be, és összefoglalják a nemzetközi orvosképzésben ezen a téren elért eredményeket.

Orv Hetil. 2020; 161(27): 1122-1130.
\end{abstract}

Kulcsszavak: integratív medicina, komplementer eljárások, orvosképzés, magyar

\section{Training concept of integrative medicine in Hungary based on international models}

\begin{abstract}
Integrative medicine is a new approach in the 21 st century healthcare system, which integrates conventional medicine and evidence-based, safe and efficient complementary therapies into a unified biomedicine. Medical doctors and complementary therapists work together in partnership with patients to help them recover and live a whole life. Equally important is the maintenance and enhancement of health and well-being in which therapists become rolemodels. In this article, the authors introduce a proposal for the concept and major elements of a two-year integrative medicine postgraduate training for specialist doctors in Hungary and summarize international progress in the field.
\end{abstract}

Keywords: integrative medicine, complementary therapies, postgraduate education, Hungarian

Eőry Aé, Szabó J, Csik I, Csupor D, Sőti Cs, Kalabay L, Varsányi P, Komsa I, Eőry Ao, Torzsa P. [Training concept of integrative medicine in Hungary based on international models]. Orv Hetil. 2020; 161(27): 1122-1130.

(Beérkezett: 2020. február 10.; elfogadva: 2020. március 23.)

\section{Rövidítések}

BNO = betegségek nemzetközi osztályozása; Btk. = büntető törvénykönyv; $\mathrm{CAM}=($ complementary and alternative medicine) komplementer medicina; DASH = (Dietary Approaches to Stop Hypertension) diétás megközelítések a hypertonia megállításához; EU = Európai Unió; FODMAP = (Fermentable Oligo-, Di-, Mono-saccharides and Polyols) fermentálható oligo-, di- és monoszacharidok, valamint poliolok; $\mathrm{HKO}=$ ha-

* Megosztott első szerzők

** Megosztott utolsó szerzők 
gyományos kínai orvoslás; ICD = (international classification of diseases) a betegségek nemzetközi osztályozására használt kódrendszer; IM = integratív medicina; MTA = Magyar Tudományos Akadémia; NCCAM = (National Center for Complementary and Alternative Medicine) Nemzeti Komplementer és Alternatív Medicina Központ

Az integratív medicina (IM) az utóbbi évtizedekben egyre szélesebb teret hódító koncepció [1-3]. Használata a konvencionális és a komplementer gyógymódok együttes alkalmazását jelenti azzal a céllal, hogy holisztikus, személyközpontú megközelítést tegyen lehetővé. A kezelés célja az egészség fenntartása, illetve a gyógyulás optimalizálása. Ennek elérésére interdiszciplináris kollaboráció keretében az orvosok és a komplementer terapeuták a beteg aktív közremúködésével individuális kezelési tervet állítanak fel [4].

A betegközpontú gyógyítás az ezredfordulón vált ismét hangsúlyossá, kifejezetten annak kapcsán, hogy a tudományos evidenciák nem a beteget, hanem a betegséget állítják az érdeklődés középpontjába, ezzel a gyógyítást kognitív-racionális folyamattá egyszerúsítve [5]. Az orvos-beteg találkozások alkalmával azonban az individuális terápiát a legjobb tudományos evidenciák mellett a beteg személyisége és pszichoszociális háttere is meghatározza [5]. A betegközpontúság tudatosítása azért is jelentős, mert az egészségügyi ellátás a rohamos tudományos és technikai fejlődésnek köszönhetően egyre komplexebbé és fragmentáltabbá válik $[6,7]$. Az amerikai Institute of Medicine 2001-ben, a XXI. század egészségügyi ellátórendszerének javítására megfogalmazott legfontosabb hat elérendő cél közé helyezte a betegközpontúságot [7]. Megfogalmazásában ez azt jelenti, hogy olyan ellátást kell biztosítani, mely „figyelembe veszi és válaszol a beteg igényeire, szükségleteire és értékeire; és biztosítja, hogy a beteg értékei irányítsanak minden klinikai döntést" [7]. Az integratív medicina az embert a maga teljességében értelmezi, és a fentebb megfogalmazott cél megvalósulását segíti elő az életmódváltással, mely alapvető stratégiája a XXI. századi gazdaságot igen jelentősen terhelő krónikus betegségek kezelésének [8]. A beteg szó szorosan összefügg a betegséggel, és a beteg ember gyakran csak passzív célpontja a terápiás beavatkozásnak [9]. Ezzel szemben a személy felelős a saját tetteiért és viselkedéséért. A személyközpontú (person-centered) modellben a beteg aktív résztvevője az ellátásának, beleértve a döntési folyamatot is, ami végső soron konkordanciát eredményez a beteg és kezelője között a terápiás terv kialakításában, javítva az egészségcélok elérését és a beteg elégedettségét [9].

$\mathrm{Az}$ integratív medicina történetileg a komplementer medicina (CAM) fogalmából nőtt ki. A komplementer medicina olyan diagnosztikai és/vagy terápiás eljárások gyưjtőfogalma, amelyeket a betegek a biomedicina kiegészítéseként vesznek igénybe, és amelyek a betegek azon igényeit elégítik ki, amelyeket a hivatalosan elérhető egészségügyi ellátórendszer nem; illetve kitágítják a medicina koncepcionális keretrendszerét [10]. A tradicionális gyógyászat (például hagyományos kínai orvoslás, ájurvédikus orvoslás, magyar népi gyógyászat) az adott nép felfogásában, hitében és tapasztalatában gyökerező tudás, készségek és gyakorlat összessége, melyet az egészség fenntartására és a testi és mentális betegségek megelőzésére, diagnózisára és kezelésére használnak [11]. Amennyiben a tradicionális gyógyászati eljárásokat más országokban alkalmazzák, úgy komplementer eljárásnak nevezik őket [11].

Az integratív medicina gyakorlásakor a komplementer eljárások nem párhuzamosan, hanem terápiás együttmúködés keretei között kerülnek felhasználásra (interdiszciplináris ellátás), mind prevenciós, mind terápiás beavatkozások esetén $[4,8,12,13]$. A XXI. századra jellemző globalizáció sokszínúvé tette a gyógyászatot, azaz egy helyen számos különböző eredetű gyógyászati megközelítést alkalmazhatnak egyszerre, melyek egymást megtermékenyítő ötletekkel, közös gyakorlattal a gyógyulást kereső betegek javát és az együttmûködő szakmák kölcsönös fejlődését és egymás iránti tiszteletét egyaránt szolgálják (medical diversity) [14]. Ez került nemzetközi szinten kifejezésre a 2022. január l-jén életbe lépő ICD-11 „tradicionális medicina” fejezetének kialakításával [15]. (Az ICD a betegségek nemzetközi osztályozására használt kódrendszer; ennek átdolgozásán alapul, de formailag ettől eltérő a magyar nyelvű BNO.)

A „tradicionális medicina” szerves része az egészségügyi ellátórendszernek, mely a leghangsúlyosabban az ázsiai országokban van jelen (Kína, India, Japán, Korea). A fejezet létrehozásával először valósul meg ezek egységesített osztályozása, és válik lehetővé monitorozásuk, illetve összehasonlításuk mind nemzetközi, mind regionális szinten. A fejezet egységesített leírásai lehetővé teszik az adatrögzítést és az országos szintû monitorozást, a hivatalos egészségügyi gyakorlat mellett megjelenő kettős dokumentálással [15]. A Magyar Tudományos Akadémia 2019. november 8-án ismertette az európai akadémiák és orvosi akadémiák szövetségeinek ezzel kapcsolatos aggodalmát (https://mta.hu/tudomany_ hirei/az-europai-akademiak-figyelmeztetnek-a-hagyomanyos-kinai-orvoslas-szabalyozatlansagaban-rejlo-kockazatokra-110117). Ezek a szervezetek az egyik problémát a betegközpontú diagnosztika szubjektivitásában látják, mely szerintük megkérdőjelezi a statisztikák minőségét; a másik problémát pedig abban, hogy „a hagyományos kínai orvoslás alapelvei alkalmatlanok arra, hogy az elfogadott tudományos módszerekkel bizonyítsák vagy cáfolják őket". Előrevetítik, hogy a fejezet megalkotásának az lesz a hatása, hogy „sokan kihasználják majd annak érdekében, hogy a hagyományos kínai orvoslás eljárásait a nyugati medicina bizonyítékalapú módszereinek alternatíváiként hirdessék". A jelen közlemény szerzői ezzel kapcsolatosan szeretnék felhívni a figyelmet az MTA Orvosi Tudományok Osztályának 
korábbi, 2011-es állásfoglalására, melyben - egyebek között - a hagyományos kínai orvoslást az l-es csoportba sorolták: „A tudományos megalapozottság megítéléséhez már elegendő információ áll rendelkezésre, illetve további tudományos megerősítés várható" (https:// mta.hu/data/dokumentumok/v_osztaly/2010_Komplementer-medicina.pdf; megtekintve: 2020. 03. 20.). Ugyanezen állásfoglalás 6. melléklete tartalmazza a hagyományos kínai orvoslás területén már elérhető (Cochrane-) evidenciák alapján a neurológiai kezelésekre vonatkozó irányelveket.

Az Institute of Medicine betegközpontú ellátás kialakítására vonatkozó útmutatását követően a National Center for Complementary and Alternative Medicine (NCCAM) ösztöndíjjal támogatott 14 amerikai orvosi egyetemet a tanrendbe kötelező tantárgyként beillesztett integratív medicina programok kialakításában [16]. Európában a komplementer medicina helyzetét az Európai Bizottság által életre hívott kutatóhálózat (CAMbrella) térképezte fel 2010 és 2012 között az FP7-es keretprogramban. Részletes összefoglalást adtak a terminológiáról, a jogi státuszáról és szabályozásáról, az emberek igényeiről és hozzáállásáról, a komplementer medicina használatáról mind a betegek, mind a kezelő személyek szempontjából, és kitekintést adtak a kutatás irányairól. Ezen túlmenően kezdeményezték egy európai intézményi struktúra kialakítását, mely a NCCAM-hez hasonlóan elősegítené a CAMbrella javaslatainak gyakorlatba való átültetését, azaz a megfelelő CAM-intervenciók beépítésével az egészségügyi ellátás evidenciaalapú reformját az EU-ban [17].

Magyarországon az MTA Orvosi Tudományok Osztálya rendszeresen ad ki állásfoglalást a komplementer medicina tárgyában (1998, 2003, 2010, 2018; https:// mta.hu/v-osztaly/az-orvosi-tudomanyok-osztalya-allasfoglalasai-106453; megtekintve: 2020. 03. 20.). Ezek az állásfoglalások azt az ügyet szolgálják, hogy a tudományos evidenciák alapján (Cochrane Database of Systematic Reviews) a szakma számára elfogadható eljárások beilleszthetők legyenek az egészségügyi ellátásba, oktatásuk a lehető legmagasabb színvonalon valósuljon meg, és kiszűrjék a dilettáns, megbízhatatlan, üzleti céllal tevékenykedő vállalkozókat. Ennek megvalósításához a jogi szabályozás felülvizsgálatát is szorgalmazták. A visszaélések elleni fellépés lehetőségét a Btk. 187., kuruzslásról szóló paragrafusának kibővítésével teremtette meg a kormány, mely 2020. február 15-én lépett életbe.

Már a 2003-as állásfoglalásban felmerül, hogy „az orvosegyetemek nem kapcsolódnak be a tudományos alapú komplementer medicina graduális és szakképzésébe" (1. pont). 2018 nyarán pedig az MTA Orvosi Tudományok Osztálya 106/2018. számú osztályhatározatában lényeges feladatként határozta meg, hogy „az egyetemi orvosi karokkal és klinikai központokkal együttmúködve - egységes, világosan áttekinthető ismeretterjesztő oktatás" kerüljön kialakításra a komplementer eljárásokról [18]. Állásfoglalásukkal összhangban a hazai egyetemek képvi- selőit tömörítő, az 'Egészségügyi ellátórendszer szakmai és módszertani fejlesztésére' létrehozott országos szintú projekt (EFOP-1.8.0-VEKOP-17) keretei között 2019 tavaszán a háziorvosi praxisközösségek dolgozóinak továbbképzésébe beépült a komplementer medicina használatának betegközpontú lehetőségeit tudományos evidenciák alapján ismertető előadás. Kidolgozásra került és a 2019-2020-as tanév tavaszi szemeszterében elindult a Semmelweis Egyetem graduális oktatásában a „Komplementer eljárások az evidenciák tükrében” című, szabadon választható tárgy, melyben a hallgatóknak lehetősége nyílik egyes komplementer eljárások tudományosevidencia-alapjainak megismerésére, a természetgyógyász (komplementer terapeuta)-beteg kapcsolat speciális szempontjainak feltérképezésére és sajátélménygyakorlatokon keresztül különböző modalitások megismerésére. Ennek alapja volt, hogy 2020. január 1-jével a Semmelweis Egyetem Családorvosi Tanszékéhez rendelten megalakult az Integratív Medicina Tanszéki Csoport, melynek feladata a graduális és posztgraduális képzés kialakítása mellett az integratív medicina gyakorlati megvalósíthatóságának és alkalmazásának vizsgálata Magyarországon.

Az integratív medicina licencvizsga ennek a folyamatnak a következő lépése. Bevezetésével kialakításra kerül a tudományos bizonyítékokon alapuló együttmúködés tudásbázisa, miközben a XXI. század igényeit szem előtt tartva, interprofesszionális együttmúködés keretei között hozzájárul a betegek gyógyulásának optimalizálásához.

A licenc bevezetésének négy célja van:

1) A prevenciós szemlélet erősítése.

2) A gyógyítás optimalizálása - kifejezetten krónikus, multimorbid betegek esetében.

3) A beteg-együttmúködés és a betegbiztonság javítása.

4) A szakorvosok kiégésének megelőzése és a hivatástudat, motiváció felélesztése, megerősítése.

\section{Módszer}

\section{Az integratín medicina licenc feltételvendszere}

Az integratív medicina licencvizsga kétéves képzéssel megszerezhető interdiszciplináris licenc, amelyet minden szakterület szakorvosa elsajátíthat, de amelynek legnagyobb relevanciája a háziorvosok szempontjából van. A képzés formai megvalósítására az ún. blended learning (vegyes oktatás) formát javasoljuk, melyben az otthon, online tananyagok segítségével elsajátított elméleti tudás gyakorlatba átültetését intenzív csoportmunka biztosítja.

A képzés első éve alapozó képzés. Ennek során a résztvevők körbejárják az integratív medicina fogalmát, használatát, a kezelés tervezését, majd megtanulják az egyes komplementer eljárások kapcsán összegyúlt tudományos evidenciákat és az eljárások gyakorlati alkalmazhatóságának területeit. Emellett az első évben megtanulják és a gyakorlatba is átültetik a motivációs interjú technikáit és 
azt a koordinációs szerepkört, mely lehetővé teszi, hogy az integratív medicina licenccel rendelkező szakorvos a beteg kezelésében szerepet játszó különböző szakterületek szakorvosaival, illetve nem orvosi végzettségü egészségügyi szakemberekkel, valamint a beteggel együttmúködve az adott beteg gyógykezelését koordinálja, és ezen keresztül optimalizálja. Az első év végén sikeresen teljesített záróvizsgával a szakorvos alkalmassá válik arra, hogy „természetgyógyásszal együtt dolgozó orvos”ként tanácsot adhasson betegének az adott betegség kapcsán számításba vehető kiegészítő eljárásokról; megbízható szakembert ajánljon betegének az adott szakterületen; illetve a betege által igénybe vett komplementer terapeuta szakmai megfelelőségét konzultációk alapján megállapítsa. Emellett alkalmassá válik arra, hogy kísérje és elősegítse a beteg gyógyulási folyamatát az alkalmazott terápiák függvényében. A képzés második évében a szakorvos egy (vagy több) szakterületet választ, melye(ke)t maga is magas szinten müvelni fog. A képzés sikeres elvégzése után integratív medicina licenccel rendelkező szakorvossá válik az elvégzett szakirány(ok)ban.

\section{Eredmények}

\section{Az integratín medicina licenc képzésének tartalma}

Az integratív medicina licenc képzése a nemzetközi gyakorlat alapján öt nagy pillérre épít: a kommunikációs alapok és az interprofesszionális menedzsment megteremtésére, az életmód-változtatásra (táplálkozás, testmozgás), a fitoterápiára (és ezen keresztül az öngyógyításra és az interakciókra), a test-elme kapcsolat gyógyító szerepére és egy tradicionális holisztikus gyógyítórendszerre, a hagyományos kínai orvoslásra. Az alábbiakban a képzés ezen pilléreit mutatjuk be röviden. Az ebben a fejezetben felsorolt irodalom a képzéshez magyar nyelven felhasználható könyveket tartalmazza.

\section{Az interprofesszionális együttmüködés menedzsmentje a holisztikus szemléletü betegellátásban}

\section{A gyógyító - gyógyítás filozófiája}

Aki segítséget kérő, beteg emberekkel foglalkozik, hivatása magas szintű ellátásához elengedhetetlen, hogy rendszeres időközönként megvizsgálja és tudatosítsa a saját viszonyát a segítséget kérő emberekhez és a hivatáshoz [19]. A gyógyító munka során rengeteg hatás éri a gyógyítót is, mely hatások jelentős változást hozhatnak létre a gyógyító szakmai, emberi kapcsolataiban [20]. Ezeket a változásokat úgy tudjuk észlelni, ha rendszeres időközönként végiggondoljuk a gyógyító munkához való viszonyunkat, tudatosítjuk erőforrásainkat és szükségleteinket, figyelünk a bennünk keletkező jó és rossz érzésekre, és elemezzük azokat és a lehetséges okokat.
Nemcsak az egyénnek, hanem az együtt dolgozó teameknek is időről időre el kell végezniük ezt a munkát, a rendszeres szupervízió a jó szakmai együttmúködés alapja és biztosítéka.

\section{A gyógyító munkacsoport}

A gyógyító munkát segítő együttmúködés alapja annak meghatározása, hogy kik a gyógyító munkacsoport tagjai, az egyes tagoknak milyen feladatuk, hatáskörük van, és hogyan történik a koordináció a munkacsoporton belül. A beteg kezelését koordináló orvosnak, egészségügyi szakembernek ismernie kell a gyógyító folyamatban részt vevő valamennyi szakembert [21]. Strukturálisan folyamatosan együtt dolgozó munkacsoportoknál ez könynyen áttekinthető, és egyértelműek a kompetenciák, feladatok is. Azokban az esetekben azonban, amikor a páciens gyógyítását egymástól függetlenül dolgozó szakemberek végzik, az együttmúködés alapvető feltétele, hogy legyen egy olyan közös felület, amelyen minden történést dokumentálnak, amelyre mindannyian rálátnak, és amelyen keresztül kommunikálni is tudnak. Egy ilyen felület lehetővé teszi, hogy a munkacsoport személyes találkozás nélkül is létrejöhessen, és együttműködésük biztosítva legyen.

\section{Konzultáció a beteggel}

A hatékony gyógyító munka fontos feltétele a beteggel történő rendszeres, őszinte és értő kommunikáció, mely a konzultációkon valósul meg [22]. Ezeknek a konzultációknak a legfontosabb eleme a kölcsönös bizalom. Ennek a bizalomnak meg kell lennie a beteg és a gyógyításában részt vevő valamennyi egészségügyi dolgozó között. A bizalom megteremtése folyamat, melyre időt kell hagyni, és a betegre történő maximális figyelemmel kell kialakítani [23]. Mivel munkánk során a hagyományos orvoslás és a komplementer medicina optimális együttmúködését kívánjuk elérni, és valamennyi segítő technikát a gyógyulás és az egészségmegőrzés érdekében kívánunk felhasználni, elengedhetetlen, hogy a beteg értse a helyzetét, és az általa megadott prioritások mentén felajánlott alternatívákban segíteni tudjuk az ő felelős döntését [24]. A konzultációk szervezése, vezetése a beteg koordinációjáért felelős orvos feladata, és a beteggel közösen kell meghatározniuk, hogy mikor, kinek a jelenléte szükséges az adott viziten.

\section{Racionális fitoterápia}

A gyógynövények terápiás alkalmazása a modern gyógyászat és gyógyszerek kialakulásának egyik fontos kiindulópontja. A népi gyógyászatból nyert tapasztalat számos fontos információval szolgált a gyógynövények hatásait, biztonságosságát illetően, ami jól hasznosítható volt a gyógyszerkutatásban, új hatóanyagok felfedezésében is. A gyógyszerkincs egy része máig kapcsolódik a fitoterápiához: számos készítmény növényi kivonatot tartalmaz, több gyógyszer hatóanyaga pedig természetes eredetű vegyület (például félszintetikus származék). 
A fitoterápia az öngyógyításban legelterjedtebben alkalmazott gyógyászati módszer, részben azért is, mert az elérhető termékek száma több tízezerre tehető. Az orvos javaslatára vagy tudtán kívül alkalmazott növényi szerek nemcsak elönyösen befolyásolhatják a terápiát, hanem adott esetben az interakciók révén károsan is. Az orvosok fitoterápiás ismereteinek bővítése elengedhetetlen, mert ismeretek hiányában bizonyos, gyógyszerként forgalmazott termékek a terápiás eszköztárukon kívül maradnak. Emellett a megnövekedett ismeretanyag és a képzés során elsajátított kommunikációs technikák hozzásegítik a képzésben részt vevôket ahhoz, hogy az orvos-beteg találkozás során beszélgetést kezdeményezzenek a beteg által használt növényi szerekről. Így a növények hatásainak, mellékhatásainak és interakcióinak, valamint a beteg szokásainak ismeretében képesek lesznek biztosítani a terápiás biztonságot.

A fitoterápia magában foglalja a népi gyógynövény-alkalmazást és a növényi termékek modern, bizonyítékokon alapuló használatát is. A tervezett képzés a racionális fitoterápia eszközeire, azaz a klinikailag is igazolt hatású gyógynövényekre fókuszál, prioritásként kezelve a hatásosság és a biztonságosság igazolását, de tárgyalva az egyéb jellemzőket, így a mellékhatásprofilt, a kölcsönhatásokat, az adagolást és a növényi szerek egyéb jellemzőit is. Bemutatásra kerülnek azok a szerek is, amelyek klinikai vizsgálata nem történt meg, de amelyek a tradícióból nyert adatok alapján gyógyszerszintû készítményekként kerülhetnek forgalomba.

A képzés során a növényeket hatástani csoportosításban mutatjuk be. Kiemelt hangsúlyt kapnak a termékminőséggel és a készítmények jogi kategóriáival (gyógyszer, étrend-kiegészítő, kozmetikum stb.) kapcsolatos alapismeretek is. A fitoterápiás képzés célja, hogy a növényi készítményeket a modern orvoslás részeként, megalapozottan legyen képes alkalmazni a szakember.

\section{Dietoterápia}

A dietoterápiás alapképzés célja, hogy a tápanyagokat a természetgyógyászatban javasolt táplálkozási rendszerek tükrében ismertesse meg, és betekintést adjon a főbb természetgyógyászati táplálkozási irányzatokba. Az irányzatokon belül az elterjedtebbeket - az eliminációs, a gyulladáscsökkentő, a DASH- és a FODMAP-diétát részleteiben is tárgyalja. Emellett betekintést nyújt a „teljes értékứ” táplálékok, táplálékkiegészítők, az egészséges ételkészítés alapjaiba és a kultúra és a családi környezet táplálkozási vonatkozásaiba. A szakirány választásával az orvosok megismerik a különböző életkorok táplálkozási igényeit (férfiak és nók esetében), a táplálkozás szerepét a primer, szekunder és tercier prevencióban, és gyakorlati oktatás keretében részletes ismereteket szereznek a táplálkozási anamnézis felvételéről, az étkezési hibák feltérképezéséről, az étrendtervezésről, valamint a különböző szervrendszerekhez tartozó betegségek táplálkozási javallatairól.

\section{A testmozgás mint gyógyszer}

A morbiditási és mortalitási listán vezetô (cardiovascularis, metabolikus, respiratorikus, onkológiai és mozgásszervi) kórképek túlnyomó többsége életmóddal összefüggó betegség, melyek primer és szekunder prevenciójában az egészséges és kiegyensúlyozott táplálkozás, a stresszmenedzsment és a szociális támogatás mellett kiemelkedő a fizikai aktivitás szerepe [25].

2012-ben a Lancet külön cikksorozatot szentelt ennek a témának, miszerint a fizikai inaktivitást - prevalenciája és egészségre gyakorolt hatása miatt - pandémiaként jellemezhetjük, melynek messzemenő egészségügyi, gazdasági, környezeti és társadalmi hatása van [26].

A testmozgás egészséghez segítő szerepéről szerzett ismereteink nem új keletúek: nemcsak megszámlálhatatlan tanulmány eredménye bizonyítja az 1950-es évektől kezdve (a Lancetben már 1953-ban jelent meg vizsgálati eredmény a testmozgásnak a coronariabetegségben kifejtett jelentős hatásáról), de már az i. e. V. században Hippokratész is hangsúlyozta a helyes étkezés mellett a testmozgás egészségfenntartó hatását. Ennek ellenére a mozgásszegény életmód (a szabadidôs tevékenységgel szemben - inkább a munkaidő mozgásszegénysége változott kedvezőtlen irányba) az utóbbi évtizedekben öltött súlyos méreteket.

A megfelelő fizikai aktivitás egészségmegőrző, gyógyulást segítő szerepe elvitathatatlan. Az, hogy hányféle testi és lelki betegség esetén van kedvező hatása a gyógyulásra, meghaladja e cikk kereteit. Ezek közül - a mozgásszervi problémák mellett - a gyakoriság szempontjából a legfontosabbak, ahol hatékonynak bizonyul: szív- és érrendszeri betegségek (kiemelten hypertonia és coronariabetegség), diabetes mellitus, obesitas és más metabolikus betegségek, onkológiai kórképek (különösen az emlő- és vastagbélrák), depresszió és más mentális kórképek, osteoporosis, valamint a különböző típusú dementiák [27]. A morbiditási mutatók mellett csökkenti a korai mortalitási rátát [28].

A testmozgás egészségre gyakorolt szignifikáns hatását és az ezt alátámasztó evidenciát senki nem vitatja, így a megfelelő fizikai aktivitás első vonalbeli terápiaként való alkalmazása érdekében 2007-ben az Egyesült Államokban, 2008-ban pedig globálisan is elindult az „Exercise is medicine" nevú program (több mint 40 ország részvételével). A szakértók világszerte egyetértenek abban, hogy az orvosi viziten a beteg fizikai aktivitását ugyanúgy fel kell térképezni, mint más, szokásosan feltárt anamnesztikus adatokat, és a beteg állapotától függően - megelőzés és/vagy kezelés céljából - megfelelő mozgásprogramot kell elő́rni neki [27]. Abban is egyetértés van, hogy bár a legkisebb testmozgásnak is lehet pozitív hatása, és az is jobb, mint az inaktivitás, a heti 150 perc, legalább közepes intenzitású testmozgás ajánlott. Ugyanakkor a betegek állapota, lehetőségeik, készség- és képességszintjeik a testedzés személyre szabását igénylik. Ennek kivitelezése további igényeket támaszt. Nemcsak az orvosképzésben fontos kiemelni a fentiek jelentőségét, hanem az alapellá- 
tásban dolgozó orvosoknak és a szakorvosoknak is hangsúlyozniuk kell a fizikai aktivitás jelentőségét a beteg felé, javaslatokkal kell elóállni, hogy az elmélet hogyan válhat gyakorlattá. Elérhető és megfelelően képzett sport- és mozgásszakemberek (testnevelők, gyógytestnevelők, gyógytornászok, edzők, mozgástanárok stb.) együttmúködésére van szükség. A program fóbb célkitűzései: folyamatos kapcsolat kialakítása az egészségügyi és az egészséggel kapcsolatos fitneszszervezetek között; mind az egészségügyi, mind a mozgásszakemberek képzése a program megvalósításához; a „testmozgás mint gyógyszer” program integrálása az egészségügyi ellátásba; és a kapcsolati háló kialakítása az orvosok és a mozgásszakemberek között, hogy a betegek „beválthassák” a fizikai aktivitásról szóló receptjüket.

A testreszabott mozgásprogram során kiemelt jelentőségű az állóképesség, az izomerő és a rugalmasság fejlesztése, és ugyanígy az ízületek védelme. Az utóbbihoz hozzájárul a helyes testtartás, valamint az egyes testrészek megfelelő pozicionálása, illetve az ideális mozgásminták kialakítása. Ezek a testet érintő statikai és biomechanikai jellemzők meghatározzák az ízületeket, izmokat ért terheléseket, ami nemcsak hozzájárul a degeneratív elváltozások késleltetéséhez, megelőzéséhez, de a betegek mindennapi fájdalmait csökkentve javítják az életminőséget, és csökkentik a gyógyszerszedés mértékét. A megfelelően végzett testmozgással és edukációval számos mozgásszervi eredetű panasz megelőzhető, vagy ha már kialakult, akkor csökkenthető vagy meg is szüntethető. A fájdalmatlan mozgás alapvető feltétele a korábbiakban megfogalmazott „mozgás mint gyógyszer” alkalmazásának.

Bizonyított előnyt jelent a megfelelő, rendszeres és személyre szabott testmozgás azáltal, hogy végzésével fejlődik az egyensúlyérzék és a mozgáskoordináció, ami tovább csökkenti az esetleges sérülések veszélyét. Ráadásul növelve a pozitív társas érintkezések számának esélyét, a betegek testi egészsége mellett a lelki és szociális jóllétüket egyaránt segíti.

\section{Gyógyítórendszerek - hagyományos kínai orvoslás}

A hagyományos kínai orvoslás több ezer éves tapasztalaton alapuló [29-31], töretlenül fejlődő gyógymód, mely saját diagnosztikai és terápiás rendszert alkalmaz [32]. Intenzív kutatását bizonyítja, hogy a PubMed adatbázisban 18588 közlemény fókuszál a témára, melyek közül 8465 klinikai kutatás és 2394 összefoglaló közlemény.

Az alapozó évben rendszerezett ismereteket kapnak a hallgatók a HKO-ban alkalmazott egészség- és betegségfelfogásról, a diagnosztikai és differenciáldiagnosztikai módszerekről és a terápiás lehetőségekről [33-35]. Emellett a nemzetközi tudományos szakirodalom alapján megismerkedhetnek azzal, hogy mely kórképekben alkalmazható eredményesen ez a módszer, milyen arányban és milyen típusú mellékhatásokra kell számítani, és milyen feltételrendszer teljesülése esetén alkalmazható Magyarországon.
Azoknak, akik ezt a szakirányt választják, lehetőségük nyílik bekapcsolódni valamelyik magyarországi egyetem által meghirdetett hagyományos kínai orvosképzésbe vagy az integratív medicina licenc képzésének keretén belül a fülakupunktúra elsajátítására. A fülakupunktúra a HKO része, melynek gyakorlati alkalmazásához jelentősen hozzájárult Paul Nogier francia neurológus [36]. A fül - mint mikrorendszer - egyszerúen és hatékonyan alkalmazható területe a HKO-nak [37], kis helyigénye és eszközigénye miatt akár túlterhelt rendelői körülmények között is eredményesen végezhető.

\section{A test-elme kapcsolat szerepe a gyógyításban}

Az egyre gyakoribb krónikus, nehezen kezelhetó és kitartást, türelmet igénylő betegségek nemcsak komplementer gyógymódok bevonását igénylik, de jelentősen terhelhetik mind az orvost, mind a beteget, stresszt és szorongást okozva, ahol a kívánatos együttmúködés helyett fellépő feszültségek negatívan hatnak a gyógyulási folyamatra. Egyre több tanulmány igazolja a tartós érzelmi distressz (szorongás, depresszió) egészségromboló hatását és különféle szomatikus betegségekkel (például diabetes, cardiovascularis betegségek) való együttes előfordulását. Az orvosi rendeléseken növekszik a mentális nehézségekkel küzdők és a konvencionális terápiára rezisztens betegek száma, ami az orvostól is új készségeket igényel. Ezzel szemben ismert, hogy a „jó orvos” hagyományos képének szerves része a nyugodt, empátiás viszonyulás, a betegek úgy érzik, már az ilyen orvos „jelenlétében" is gyógyulnak. Ezen túl az orvos jelenlétében vagy általa beadott gyógyszerek (vagy placebo) hatékonysága jelentősen felerősödik. A gyógyult, elégedett és hálás beteg az orvosában is az elégedettség, a képesség és a hála érzéseit erősíti. Hogyan járul hozzá az orvos érzelmi állapota a gyógyításhoz? Hogyan tudja a saját jóllétét elősegíteni és a gyógyító folyamatban önmagával és betegével megfelelően együttmúködve megvalósítani a kapcsolatban rejlő gyógyító potenciált?

$\mathrm{Az}$ alapozó képzés során az utóbbi két évtized pszichológiai és idegtudományi eredményeinek köszönhetően megismerhetik az orvos-beteg kapcsolatot irányító tudattalan érzelmi és kötődési minták neuropszichológiai alapjait, az érzelmi reguláció és koreguláció jelentőségét, az elme különböző tartalmainak (romboló hiedelmek, traumatikus emlékek és magasabb rendú érzések) érzelmi-fiziológiai hatásait. Ezáltal felismerhetik betegeik kapcsolódási mintáit, és megérthetik érzelmi igényeiket, felfedezhetik és visszatükrözhetik képességeiket, erősségeiket. Betekintést nyerhetnek a különféle tudatállapotok sajátosságaiba és a tudatossággal foglalkozó eljárások hatásaiba. Ennek alapján hatékonyabb együttmúködést folytathatnak a megfelelő mentális vagy komplementer eljárással foglalkozó szakemberrel.

A képzés gyakorlati részében az elméleti részhez kapcsolódó, egyszerü sajátélményü testtudatos és imaginatív gyakorlatokat tanulnak, melyeket saját életükben érzelmi egyensúlyuk kiterjesztésére, az öngondoskodás (self- 
care) és az önreflexió hatékonyabbá tételére fel tudnak használni, és eszközként betegeiknek meg tudnak tanítani. Légzésmeditációs saját élmény kapcsán megtapasztalják a kitágult tudatosságú állapotok szerepét aktuális érzelmi állapotuk, valamint belső erőforrásaik azonosításában és testi leképezésében, motivációik és nehézségeik azonosításában és átformálásában, mélyebb kapcsolódást, értelmet, saját spirituális útmutatást nyerhetnek. Végül készségeket kaphatnak a beteg gondolati-érzelmi állapotára való ráhangolódásban és az együttérző támogatás megadásában.

\section{Kitekintés}

\section{Amerikai Egyesült Államok}

A komplementer medicina (CAM) egyetemi oktatása az Amerikai Egyesült Államokban 1993-ban már bevezetésre került az Arizonai Egyetemen [38]. Mivel a népesség érdeklődése e módszerek iránt folyamatosan nőtt, egyre több egyetemen vezették be oktatását szabadon választható tárgyak formájában. Az American Association of Medical Colleges 1997-98-ban az egyetemek felmérése kapcsán azt találta, hogy 64\%-uknál valamilyen formában elérhető ez a terület [39]. Az Institute of Medicine 2005-ben megjelentetett jelentésében összefoglalta a CAM-használat jellegzetességeit, az ezen a téren zajló kutatásokat, és meghatározta annak keretrendszerét, hogy a validált eljárásokat beépítsék a konvencionális terápiába [40]. Ez vezetett az NCCAM ösztöndíjpályázatához, mely az amerikai orvosképzésbe

1. táblázat |A komplementer eljárások orvosképzésbe integrálásának okai az amerikai egyetemi képzőhelyek gyakorlati tapasztalatai alapján [16]

1. A komplementer terápiák használatának prevalenciája növekszik az Amerikai Egyesült Államokban.

2. Az oktatással kormányzati, törvényi vagy egyéb felhívásokra reagálnak.

3. Szükséges, hogy a beteg és az egészségügyi ellátó személyzet között a CAM-használatra vonatkozó kommunikáció javuljon.

4. A CAM-használat biztonságosságát fokozni kell, beleértve a gyógyszeres vagy egyéb, CAM-kezelések közötti interakciók kockázatának csökkentését.

5. A CAM-oktatásnak pozitív hatása van a biomedicinát alkalmazó egészségügyi szakemberek alapvető kompetenciáinak növelésében.

6. A CAM oktatásának pozitív hozadéka van a kulturális kompetencia és a betegközpontú ellátás javításában.

7. A képzés jó szaktudású és kulturálisan kompetens szolgáltatókkal hozzájárulhat az egészségügyi koordináció javításához.

8. A képzés fokozhatja a képzőhelyek kutatási kapacitását.

9. A képzés javíthatja a kutatás minőségét.

10. A képzés emelheti az ellátás színvonalát.

$\mathrm{CAM}=$ komplementer medicina kötelező tárgyként bevezetett komplementer és integratív medicina oktatásának tudományos szakirodalmát jelentősen megnövelte [16]. A képzéssel elősegítették, hogy a klinikusok megfelelő információk alapján, előítélettől mentesen tudják betegeiket CAM-használati szokásaikról kérdezni, és evidenciákon alapuló tanáccsal tudják őket ellátni egy adott komplementer terápia hasznáról vagy káráról [41]. Az 1. táblázat azt mutatja, hogy gyakorlati tapasztalataik alapján a képzóhelyek a CAM oktatásának indokait miben látták [16].

Ezt a szemléletet tágítja ki Benjamin és mtsai közleménye [42], akik nagy hangsúlyt helyeztek az integratív medicina interperszonális oldalára, kiemelve, hogy az egészségügyi szakemberek és a komplementer terapeuták közötti partnerkapcsolat nagyon fontos, és tanítani kell a hatékony kommunikációt mind a beteg, mind a komplementer szakemberek irányában.

Az integratív medicina egyetemi oktatásával megszerezhető kompetenciákat [43] a Semmelweis Egyetem Családorvosi Tanszékének honlapján lehet elérni, illetve a levelező szerző készséggel továbbítja megkeresés esetén.

\section{Ausztrália}

Ausztráliában 2005-ben a Royal Australian College of General Practitioners és az Australian Integrative Medicine Association közös állásfoglalást adott ki a komplementer medicináról [44], melyben felhívja a szakmai testületeket, hogy ugyanolyan információforrásokat hozzanak létre a komplementer eljárásokról a háziorvosok részére, mint amilyenek rendelkezésre állnak a konvencionális medicináról [44]. A háziorvosokat pedig felhívja arra, hogy kérdezzék ki betegeiket a természetgyógyászati módszerek alkalmazásáról, és vegyék ezeket figyelembe betegségeik kezelésekor. Szükségesnek tartja, hogy a háziorvosok jól informáltak legyenek a komplementer eljárásokról, hogy szükség esetén tanácsot adhassanak betegeiknek ezen a téren $[44,45]$. Szükségesnek tartják a háziorvosok graduális és posztgraduális képzését a természetgyógyászati módszerekről, ami lehetővé teszi, hogy az evidenciákon alapuló módszerekról ne csak információkat adhassanak betegeiknek, de azokat terápiás gyakorlatukba is beépíthessék.

\section{Európa}

Európai egyetemeken 1999-ben kérdőíves felmérést végeztek a nem konvencionális medicina oktatásáról. A válaszadó orvosi egyetemek 40\%-a nyújtott képzést ezen a téren, az egészségtudományi karok $72 \%$-a, és az oktatás egyéb egyetemek 8\%-ánál is megtalálható volt [46]. Az Európai Unió 7-es keretprogramjában támogatta, hogy az Unió tagországainak akadémiai szakértőiből létrehozott kutatóhálózat áttekintse a komplementer medicina helyzetét, és stratégiát állítson fel a komplementer eljárások kutatására (https://cam-europe.eu/library-cam/ 
cambrella-research-reports). A feltárt evidenciák alapján a komplementer eljárások jogi szabályozása tagországonként jelentős különbségeket mutat, jelezve az egyes országok speciális szempontrendszerét ezzel a területtel kapcsolatban [47]. Mivel a kutatás alapjaiban határozza meg az integrációt, a CAMbrella-munkacsoport vezetói által megfogalmazott kutatási célokat ismertetjük, mert ezek elősegíthetik az európai helyzet egységesítését. A szakértők javasolják a komplementer eljárások prevalenciájának feltérképezését egységes felépítésű kérdőívvel, az európai polgárok igényeinek felmérését; a komplementer eljárások biztonságosságának feltérképezését; valamint az integrációban alkalmazott modellek erősségeinek és gyenge pontjainak áttekintését, az innovatív módszerek alkalmazását. Emellett fontosnak tartják a CAM mint kiegészítő vagy alternatív kezelési stratégia hatásosságának vizsgálatát a klinikai gyakorlatban és a környezet és a jelentéstartalom terápiás hatékonyságának vizsgálatát a komplementer kezelések kapcsán [48].

\section{Következtetés}

A XXI. század sajátosságaként megjelenő sokszínú kultúra, a betegek számára szabadon elérhető különböző gyógyulási lehetőségek szükségessé teszik mind a graduális, mind a posztgraduális orvosképzés szintjén egy szélesebb tudásalap kialakítását. Ennek megalapozását, az irányvonalak lefektetését célozza jelen közleményünk. Az oktatás célja, hogy az orvosok hiteles információkkal felvértezve betegeik javát szolgálják egy sokszínü, komplex világban. A nemzetközi szakértői vélemény a graduális képzés kapcsán kiemeli, hogy a komplementer medicina oktatásával a hallgatók megismerik a betegek által használt sokféle eljárást, és viták és párbeszéd generálásával fel lehet készíteni őket arra, hogy ezen a területen is képesek legyenek betegeikkel együttmúködni, miközben javul a terápiás modellekkel kapcsolatos kritikai készségük [49]. Szakorvosi szinten is a komplementer eljárások növekvő használata teszi elengedhetetlenné a képzést. Ha a szakorvos tisztában van a különböző terápiákkal és azok evidenciaalapjaival, akkor betegeivel párbeszédet tud kezdeményezni erről; ezen keresztül rálátása lesz a konvencionális medicina és a párhuzamosan alkalmazott komplementer eljárások lehetséges interakcóira. Lehetővé válik, hogy a szükséges vagy az erősebb evidenciákkal rendelkező kezelést ne késve kapja meg a beteg; javuljon az előny-kockázat arány más kezelésekhez vagy a kezelés elmaradásához képest; illetve a javasolt terápiák azon a megalapozott elváráson alapuljanak, hogy kedvező lesz a kimenetelük a beteg szempontjából - a megelőző eljárásokat is beleértve [50]. Egy ilyen kapcsolat javíthatja a betegek terápiás együttmúködését a konvencionális terápiák használata iránt is. Emellett az orvos az ő személyes értékrendjének legjobban megfelelö eljárásokat beépítheti a saját klinikai gyakorlatába [50], vagy képes lesz hatékonyan együttmúködni komplementer terapeutákkal.
Anyagi támogatás: A közlemény megírása anyagi támogatásban nem részesült.

Szerzôi munkamegosztás: E. Aé., Sz. J., T. P. és E. Ao. alkották meg a tartalmi koncepciót. E. Aé. végezte a nemzetközi szakirodalom gyưjtését és elemzését, valamint E. Ao.-val együtt a hagyományos kínai orvoslás tananyagának összeállítását. Sz. J. állította össze az interprofesszionális teammunka holisztikus szemléletű menedzsmentjére vonatkozó anyagot. Cs. D. és V. P. írta a fitoterápia, K. I. a dietoterápia, S. Cs. a test-elme kapcsolat szerepe a gyógyításban képzési tervet. Cs. I. a testmozgás gyógyító szerepének alapkoncepcióját fektette le. K. L. kritikai észrevételeivel és javaslataival érdemben hozzájárult a közlemény kialakításához. Minden szerző részt vett a közlemény tartalmi és formai revíziójában. A cikk végleges változatát valamennyi szerző elolvasta és jóváhagyta.

Érdekeltségek: A szerzőknek nincsenek érdekeltségeik.

\section{Irodalom}

[1] WHO traditional medicine strategy: 2014-2023. World Health Organization, Geneva, 2013. Available from: https://www. who.int/medicines/publications/traditional/trm_strategy14_23/en/ [accessed: February 9, 2020].

[2] The Berlin Agreement: Self-responsibility and social action in practicing and fostering integrative medicine and health globally. J Altern Complement Med. 2017; 23: 320-321. Available from: https://www.ecim-iccmr.org/fileadmin/ecim-iccmr/editors/ documents/Berlin_Agreement_on_Self-Responsibility_160417. pdf [accessed: February 9, 2020].

[3] Weeks J. Endorsement invited for global "Berlin Agreement" on self-responsibility and social action in integrative health ... plus more. Integr Med (Encinitas). 2017; 16: 20-23.

[4] Hu XY, Lorenc A, Kemper K, et al. Defining integrative medicine in narrative and systematic reviews: a suggested checklist for reporting. Eur J Integr Med. 2015; 7: 76-84.

[5] Bensing J. Bridging the gap. The separate worlds of evidencebased medicine and patient-centered medicine. Patient Educ Couns. 2000; 39: 17-25.

[6] Barry MJ, Edgman-Levitan S. Shared decision making - pinnacle of patient-centered care. N Engl J Med. 2012; 366: 780-781.

[7] Institute of Medicine (US) Committee on Quality of Health Care in America. Crossing the quality chasm: a new health system for the 21 st century. National Academies Press (US), Washington, DC, 2001. Available from: http://www.ncbi.nlm.nih. gov/books/NBK222274/ [accessed: February 9, 2020].

[8] Maizes V, Rakel D, Niemiec C. Integrative medicine and patientcentered care. Explore N Y 2009; 5: 277-289.

[9] Ekman I, Swedberg K, Taft C, et al. Person-centered care - ready for prime time. Eur J Cardiovasc Nurs J. 2011; 10: 248-251.

[10] Ernst E, Resch KL, Mills S, et al. Complementary medicine - a definition. Br J Gen Pract. 1995; 45: 506.

[11] WHO global report on traditional and complementary medicine, 2019. World Health Organization, Geneva, 2019.

[12] Boon H, Verhoef M, O'Hara D, et al. Integrative healthcare: arriving at a working definition. Altern Ther Health Med. 2004; 10: $48-56$.

[13] Ng JY, Boon HS, Thompson AK, et al. Making sense of "alternative", "complementary", "unconventional" and "integrative" medicine: exploring the terms and meanings through a textual analysis. BMC Complement Altern Med. 2016; 16: 134. 
[14] Penkala-Gawęcka D, Rajtar M. Introduction to the special issue "medical pluralism and beyond". Anthropol Med. 2016; 23: 129-134.

[15] ICD-11 Implementation or Transition Guide. World Health Organization, Geneva, 2019. License: CC BY-NC-SA 3.0 IGO.

[16] Gaylord SA, Mann JD. Rationales for CAM education in health professions training programs. Acad Med. 2007; 82: 927-933.

[17] The Roadmap for European CAM Research. An explanation of the CAMbrella project and its key findings. Available from: https://cam-europe.eu/wp-content/uploads/2018/09/ cambrella-roadmap.pdf [accessed: February 9, 2020].

[18] Section of Medical Sciences, Hungarian Academy of Sciences. Principles of evidence-based medicine and complementary methods. [Magyar Tudományos Akadémia, Orvosi Tudományok Osztálya. A bizonyítékokon alapuló orvoslás elvei és a komplementer eljárások.] MTA, Budapest, 2018. Available from: https://tudomany.hu/cikkek/a-bizonyitekokon-alapuloorvoslas-elvei-es-a-komplementer-eljarasok-108957 [accessed: February 9, 2020]. [Hungarian]

[19] Szepesvári E, Schnell E. Holistic Medicine. [Holisztikus medicina.] Golden Book Kiadó, Budapest, 1996. [Hungarian]

[20] Walsch DN. Holistic living. [A holisztikus életrôl.] Édesvíz Kiadó, Budapest, 2000. [Hungarian]

[21] Groopman J. How doctors think. [Hogyan gondolkodnak az orvosok?] Akadémiai Kiadó, Budapest, 2011. [Hungarian]

[22] Pilling J. Medical communication in practice. [Orvosi kommunikáció a gyakorlatban.] Medicina Könyvkiadó, Budapest, 2018. [Hungarian]

[23] Levounis P, Arnaout B, Marienfeld C. Motivational interview in clinical practice. [Motivációs interjú a klinikai gyakorlatban.] Oriold és Társai Kiadó, Budapest, 2018. [Hungarian]

[24] Varga K. Solutions. [Helyzet + oldások.] Medicina Könykiadó, Budapest, 2013. [Hungarian]

[25] Li Y, Pan A, Wang DD, et al. Impact of healthy lifestyle factors on life expectancies in the US population. Circulation 2018; 138: 345-355. [Correction: Circulation 2018; 138: e75.]

[26] Kohl HW 3rd, Craig CL, Lambert EV, et al. The pandemic of physical inactivity: global action for public health. Lancet 2012; 380: 294-305.

[27] Sallis R. Exercise is medicine: a call to action for physicians to assess and prescribe exercise. Phys Sportsmed. 2015; 43: 22-26.

[28] Blair SN, Wei M. Sedentary habits, health, and function in older women and men. Am J Health Promot. 2000; 15: 1-8.

[29] Neijing HD, Wen S. The Yellow Emperor's classic of internal medicine - Simple questions. [A Sárga Császár belső könyvei Egyszerú kérdések.] Fapadoskonyv.hu, Budapest, 2012. [Hungarian]

[30] Neijing HD, Shu L. The Yellow Emperor's classic of internal medicine - Spiritual axis (excerpts). [A Sárga Császár belső könyvei - Szellemi tengely (szemelvények).] Fapadoskonyv.hu, Budapest, 2012. [Hungarian]

[31] Huang Di Bashiyi Nan Jing. The classic of difficult issues - Canon of the Yellow Emperor's eighty-one difficult issues. [Nehéz Kérdések Könyve: A Sárga Császár nyolcvanegy nehéz kérdésének könyve.] Fapadoskonyv.hu, Budapest, 2012. [Hungarian]

[32] Ernst E, Pittler MH, Wider B, et al. Oxford Handbook of Complementary Medicine. Oxford University Press, Oxford, 2008.

[33] Kaptchuk TJ. The web that has no weaver. Millennial tradition: Chinese medicine: philosophical, theoretical and practical basics. [Évezredek hagyománya: A kínai orvostudomány: Filozófiai, elméleti és gyakorlati alapok.] Magyar Akupunktúra és Moxatherápiás Egyesület, Budapest, 1992. [Hungarian]
[34] Pálos I, Csongor B, Szilárd R. Traditional Chinese medicine. [A hagyományos kínai orvoslás.] Gondolat Kiadó, Budapest, 1963. [Hungarian]

[35] Dravetzky É. Acupuncture - theory, practice: based on the lectures of Professor Pálos of traditional Chinese medicine. [Akupunktúra - elmélet, gyakorlat: a hagyományos kínai orvoslás Pálos professzor előadásai alapján.] Dr. Haller Média Kiadó, Pécs, 2000. [Hungarian]

[36] Nogier P. Practical introduction to Nogier ear treatment. [Gyakorlati bevezetés a Nogier-féle fülkezeléshez.] Konzunion-Akupunktúra Online Bt., 2004. [Hungarian]

[37] Landgren K. Ear acupuncture: a practical guide. lst edition. Churchill Livingstone, Edinburgh, New York, NY, 2008.

[38] Maizes V, Horwitz R, Lebensohn P, et al. The evolution of integrative medical education: the influence of the University of Arizona Center for Integrative Medicine. J Integr Med. 2015; 13: 356-362.

[39] Wetzel MS, Eisenberg DM, Kaptchuk TJ. Courses involving complementary and alternative medicine at US medical schools. JAMA 1998; 280: 784-787.

[40] Institute of Medicine (US) Committee on the Use of Complementary and Alternative Medicine by the American Public. Complementary and Alternative Medicine in the United States. National Academies Press (US), Washington, DC, 2005. Available from: https://www.ncbi.nlm.nih.gov/books/NBK83799/ [accessed: February 9, 2020].

[41] Frenkel M, Frye A, Heliker D, et al. Lessons learned from complementary and integrative medicine curriculum change in a medical school. Med Educ. 2007; 41: 205-213.

[42] Benjamin PJ, Phillips R, Warren D, et al. Response to a proposal for an integrative medicine curriculum. J Altern Complement Med. 2007; 13: 1021-1033.

[43] Kligler B, Maizes V, Schachter S, et al. Core competencies in integrative medicine for medical school curricula: a proposal. Acad Med. 2004; 79: 521-531.

[44] Royal Australian College of General Practitioners-Australasian Integrative Medicine Association. RACGP-AIMA Joint Position Statement on Complementary Medicine - 2004. Available from: https://www.racgp.org.au/download/documents/Policies/ Health\%20systems/complementary_medicine.pdf [accessed: February 9, 2020].

[45] Hunter J, Leeder S. Patient questionnaires for use in the integrative medicine primary care setting. A systematic literature review. Eur J Integr Med. 2013; 5: 194-216.

[46] Barberis L, de Toni E, Schiavone M, et al. Unconventional medicine teaching at the Universities of the European Union. J Altern Complement Med. 2001; 7: 337-343.

[47] Wiesener S, Falkenberg T, Hegyi G, et al. Legal status and regulation of complementary and alternative medicine in Europe. Forsch Komplementmed. 2012; 19 (Suppl 2): 29-36.

[48] Fischer F, Lewith G, Witt CM, et al. A research roadmap for complementary and alternative medicine - what we need to know by 2020. Forsch Komplementmed. 2014; 21: el-el6.

[49] Brosnan C, Turner BS. (eds.) Handbook of the sociology of medical education. lst edition. Routledge, London, 2009.

[50] Royal Australian College of General Practitioners. IM16 - Integrative medicine contextual unit. RACGP, East Melbourne, 2016. Available from: https://www.racgp.org.au/education/ education-providers/curriculum/contextual-units/processes/ iml6-integrative-medicine [accessed: February 9, 2020].

(Eőry Ajándék dr., Budapest, Stáhly u. 9., 1085 e-mail:ajandekeory@gmail.com)

A cikk a Creative Commons Attribution 4.0 International License (https://creativecommons.org/licenses/by/4.0/) feltételei szerint publikált Open Access közlemény, melynek szellemében a cikk bármilyen médiumban szabadon felhasználható, megosztható és újraközölhetö, feltéve, hogy az eredeti szerző és a közlés helye, illetve a CC License linkje és az esetlegesen végrehajtott módositások feltüntetésre kerülnek. (SID_1) 